\title{
Indien efter 2014
}

\section{Freddy Svane}

\section{Med valget i april og maj i 2014 vil et nyt Indien blive formet - et Indien hvor korruption effektivt vil blive bekæmpet, hvor politiske reformer vil blive iværksat og gennemført, og hvor en effektiv politisk ledelse vil gå efter at udløse Indiens meget store potentialer}

I april og maj måned vil Indiens 1,2 milliarder mennesker gå til stemmeurnerne. Mere end 900.000 valgsteder vil give Indiens næsten 800 millioner vælgere mulighed for at vælge deres nye repræsentanter til det indiske parlament (Lok Sabha). Dermed vælger verdens største demokrati deres 16 . forsamling, og flertalslederen vil overtage landets ledelse.

I sig selv en kraftpræstation i en nation, der måske repræsenterer det mest multikulturelle samfund i verden. Det siges, at Indien befinder sig i et permanent valg enten lokalt, regionalt eller nationalt. Næppe noget andet sted i verden er demokratiet så rodfæstet $\mathrm{og}$ så uomtvistet som i Indien.

Det demokratiske Indien fødtes og formedes af Mahatma Gandhis frihedsbevægelse og blev en realitet, da Storbritannien i 1947 forlod Indien. Nok bragte den britiske kolonimagt sproget, jernbanen og det administrative system til Indien, men friheden og demokratiet var Kongrespartiets fortjeneste. Med dem skabtes verdens største demokrati.

Det forestående valg adskiller sig fra de tidligere valg, idet den voksende middelklasse, som måske udgør omkring 300 millioner mennesker, ikke længere vil stemme efter traditionelle linjer. Og med mere end 155 millioner førstegangsvælgere vil det unge Indien desuden denne gang få en afgørende indflydelse. Deres ønsker om økonomisk og social frihed vil være en markant drivkraft, og deres stemmer vil falde på den kandidat, som kan realisere deres middelklassedrømme. 


\section{Indien som vækstmarked}

Valget vil først og fremmest blive en kamp mellem Kongrespartiet og det store oppositionsparti Bharatiya Janata Party (BJP).

I mere end 40 år har Nehru/ Gandhi-familien regeret Indien, kun afbrudt af få perioder. Nehru, der blev Indiens første premierminister, efterfulgtes af datteren Indira Gandhi. Efter attentatet mod Indira Gandhi i 1984 overtog sønnen Rajiv. Ved Rajivs død i 1991 overtog dennes italienskfødte hustru Sonia Gandhi reelt roret. Over tid blev hendes magt så omfattende, at hun ofte - med rette - er beskrevet som verdens mest magtfulde kvinde.

Som ubestridt leder af Kongrespartiet har hun sat kursen for en mere socialt orienteret politisk udvikling. Dette er gået hånd i hånd med premierminister Manmohan Singhs markedsøkonomiske reformer. Singh, som overtog regeringsledelsen i 2005, var hovedarkitekten bag Indiens markedsåbning, som tog fart i begyndelse af 1990'erne. Disse reformer lagde grundlaget for Indiens position som et af verdens mest interessante markeder. Indien blev af samme grund en del af de såkaldte BRIK-lande.

Ved valget i 2004 vandt Kongrespartiet retten til at styre landet, og under denne valgperiode gennemførte regeringen (United Progressive Alliance - UPA I) betydelige reformer. Med øget vækst og med sti- gende udenlandske investeringer udviklede Indien sig til en vigtig brik blandt de såkaldte vækstmarkeder. Alverdens statsoverhoveder flokkedes om Indien og dets - syntes det - ubegrænsede markedsmuligheder. Indien blev en nødvendig del af alle landes og virksomheders vækststrategi. Man talte om det nye Kina. Attraktionen var stor, og fascinationen i omverdenen bredte sig. Dette store demokrati og dets vestligt orienterede middelklasse tiltrak statsledere og forretningsfolk fra hele verden. Mulighederne var store og optimismen ubegrænset.

Ved valget i 2009 fik UPA II flertal til at fortsætte i sin anden valgperiode. Den valgperiode som nu løber ud. Indien klarede sig ganske godt uden om den globale finanskrise takket være et solidt banksystem. De muligheder, som dette gav Indien for at fortsætte en positiv udvikling, blev imidlertid ikke indfriet. Efter vækstrater som nåede næsten 10 pct., gik det hurtigt ned ad bakke, og i dag har Indien en vækst på under 5 pct. I sammenligning med Vesten er det en meget høj vækst.

Væksten skal dog sættes i forhold til Indiens udfordringer. For at holde trit med de løbende udfordringer skønnes det, at Indien mindst skal vokse med 8 pct. årligt.

\section{Off-grid India}

Indien står i dag - som altid - over for omfattende udviklingsmæssige 
udfordringer inden for stort set samtlige samfundsområder. Det gælder inden for sundhed, uddannelse, sanitet og afskaffelse af fattigdommen.

7-800 millioner mennesker lever i dag i det såkaldte 'off-grid India' uden adgang til basale livsfornødenheder inden for elektricitet, vand, sanitet, infrastruktur og sundhed såvel som uddannelse. Indiens imponerende økonomiske vækst siden liberaliseringen i 1991 har kun i et begrænset omfang været inklusiv. Trods mange, men også meget dyre initiativer er det kun i begrænset omfang lykkedes at fordele de økonomiske gevinster til alle indere.

En særlig udfordring er manglen på infrastruktur, som kan sikre denne store befolkningsgruppe i offgrid India forbindelse med det moderne vækstsamfund. Trods udfordringerne er millioner af indere løftet ud af fattigdom, og det indiske samfund er præget af konstante forandringer og bevægelser. Hvert år løftes skønsmæssigt 10-15 millioner ud af fattigdom.

På andre områder har Indien ikke mindst takket været moderne teknologi i indisk version - gjort kvantespring. Det gælder især inden for mobiltelefoni, hvor man i dag skønner, at der er mindst 8-900 millioner mobilkunder. Mobilen har givet millioner af fattige indere nye muligheder. Denne udvikling fortsætter og vil markere en overgang fra et udviklingsland til en moderne vækstøkonomi. Drivkraften i denne udvikling vil være de unge og middelklassen. Deres stemmer vil forandre Indien og skabe nye udfordringer internt som eksternt, men også åbne op for nye muligheder.

Det er på den baggrund, at valget inden for de næste måneder skal ses.

Valgkampen synes i stigende grad at udvikle sig til en tvekamp mellem BJP's udpegede premierministerkandidat Narendra Modi og Kongrespartiets kampagneleder Rahul Gandhi. Den uformelle valgkamp er allerede i gang og fremstår meget amerikansk. Med moderne sociale medier mobiliseres størstedelen af Indiens befolkning. I megabyerne, i landsbyerne og ude på landet engageres borgerne. De politiske ledere arrangerer kæmpestore vælgerm øder med deltagelse af hundredtusindvis af mennesker.

\section{Tvekampen}

Det sprudlende indiske demokrati og dens hårdtslående medier skrevne som uskrevne, lokalsprogede som engelske - debatterer valget og dets temaer. Hovedtemaer er bekæmpelse af korruptionen, genopretning af den indiske økonomi og effektiv regeringsledelse.

Et særligt tema knytter sig til Gandhi-familiens rolle kontra den almindelige inder. Diskussionen om Gandhi-dynastiet og dets traditionelle eneret på landets ledelse er cen- 
trum for ophidsede debatter. Gandhifamiliens rolle i Kongrespartiet og i landets ledelse har været markant. I takt med at de økonomiske reformer lader vente på sig, og i takt med at korruptionen ikke er bragt under kontrol, øges kritikken mod Kongrespartiet og især dets ledelse.

Et tilbageblik viser, at Indien ikke ville have været det samme uden Gandhi-familiens ledelse, men med den konstante forandring af samfundet og med opvæksten af en selvbevidst middelklasse søges andre ledere.

Én af disse er Gujarats chiefminister Narendra Modi. Modi har siden 2001 været chiefminister for delstaten Gujarat. Delstaten, der har en befolkning på størrelse med Storbritannien, regnes blandt de mest udviklede delstater. Korrekt er det, at Gujarat over årene har fremvist meget betydelige vækstrater inden for stort set samtlige områder. Tillige er Gujarat én af de få delstater, som har en velfungerende og sammenhængende infrastruktur, ligesom man har overskud af elektricitet.

Chiefminister Modi har delt vandene nationalt og i et vist omfang også internationalt. Dette skyldes hans påståede ageren i forbindelse med de uroligheder i Gujarat i 2002, som kostede flere tusinde muslimer livet. Trods omfattende anklager er der aldrig tilvejebragt noget bevis for Modis rolle i urolighederne. Modi er blevet frikendt ad flere omgange og er følgelig aldrig blevet dømt. Trods fuldstændig frikendelse bringes Modis rolle fortsat konstant frem.

Modi er kendt for at være en effektiv, erhvervsvenlig og ukorrupt leder, som har skabt et meget erhvervsvenligt klima. Af samme grund tiltrækker Gujarat mange udenlandske investeringer. Han ses derfor som en stærk og handlekraftig politiker, som kan få tingene gjort.

Kritikere opfatter ham som hindunationalist og som en fare mod Indiens sekulære stabilitet. For mange indere, herunder middelklassen, fremstår han imidlertid som den fødte leder, som kan bringe Indien ud af det aktuelle dødvande - også ledelsesmæssigt.

Over for Modi står Kongrespartiet, som ledes af Gandhi-familien. Den reelle leder Sonia Gandhi synes at træde mere og mere i baggrunden til fordel for sønnen Rahul Gandhi. Til trods for at Rahul Gandhi qua familieskabet i manges øjne vil være den naturlige leder af Indien, synes mange iagttagere også at være enige om, at Rahul ikke udstråler en stærk interesse i at overtage de traditionelle familieforpligtelser.

Modi og Rahul Gandhi er uomtvistet det forestående valgs hovedpersoner. Indbyrdes to yderst forskellige kandidater med stærkt forskellige baggrunde. Medens Rahul kommer fra Indiens 'førstefamilie' og dermed en privilegeret baggrund, så er Modi født i en fattig familie og har ernæret sig som tesæl- 
ger. Hertil kommer, at Modi har reel og praktisk erfaring som politiker og leder og kan henvise til konkrete resultater. Rahul Gandhi har ikke haft noget direkte regeringsansvar, om end partiarbejdet har givet erfaringer.

Valgkampen vil sætte fokus på, hvordan Indien skal udvikle sig, og hvordan man gør op med den udbredte korruption og ineffektivitet. Middelklassen og erhvervslivet ønsker hurtig og effektiv ledelse. Middelklassen, der ikke bindes af traditionelle bånd til religion og familiebaggrund, er langt mere interesseret $\mathrm{i}$ at skabe en bedre tilværelse for sig selv og den nære familie.

\section{En ung befolkning}

Indien står med en meget ung befolkning, og det vurderes, at 60-70 pct. af befolkningen er under 35 år. Traditionelt kaldes det den demografiske dividende. Det er en enestående mulighed set i lyset af den vestlige verdens og Kinas hastige aldring. Det fordrer imidlertid et veludbygget og effektivt uddannelsessystem, helst med verdensklasseinstitutioner. I modsat fald vil Indien stå med en stor byrde, som dramatisk vil øge Indiens allerede store udfordringer. Tilsvarende har Indien mange iværksættere, som er opsat på at skabe deres eget. Oftest går det via et uddannelsesophold fortrinsvis i USA. Hjemvendt starter disse veluddannede indere deres egne virksomheder primært med fokus på IT og innovation. Nye innovative løsninger og produkter udvikles og skaber mange arbejdspladser.

Det er imidlertid næppe nok, eftersom Indien har behov for at etablere mindst en million job om måneden for at følge med befolkningsudviklingen. Dette kan kun gennemføres via en effektiv ledelse og en målrettet fokus på at udvikle Indiens mange muligheder.

Uanset hvem der vinder valget, er der behov for hurtige og effektive beslutninger. Såfremt dette ikke sikres, vil Indiens udfordringer stige. Konsekvensen heraf er færre muligheder for mange mennesker, som også gerne vil have del i den økonomiske fremgang. Den unge befolkning vil næppe se passivt til. Man vil kræve handling. Hvordan disse ønsker kan omsættes politisk, er fortsat uafklaret.

At den indiske befolkning ikke længere blot ønsker at se til passivt, gav Anna Hazares folkebevægelse mod korruption et ganske godt forvarsel om. Anna, en tidligere soldat, mobiliserede i løbet af meget kort tid millioner af almindelige indere $\mathrm{i}$ kampen mod korruption. Gennem sultestrejker og omfattende demonstrationer blev Indiens traditionelle politiske etablissement udfordret. Rådvildheden bredte sig, og Anna blev med ét slag symbolet på, at den almindelige inder var træt af politikeres og embedsmænds uhæmmede forsøg på at berige sig selv. Anna øn- 
skede imidlertid ikke at omsætte mobiliseringen til en politisk platform. Hans nærmeste rådgiver, den tidligere embedsmand Arvind Kejriwal fra skattevæsenet, tog imidlertid udfordringen op. Ved det netop afholdte delstatsvalg i Indiens hovedstad Delhi stormede hans parti Aam Aadmi Party (Borgerpartiet) ind med 27 mandater og afsatte byens chiefminister, Dikshit, efter 15 års Kongresstyre.

Kejriwal, der støttes af Kongrespartiet, har med en omfattende aktivisme og meget utraditionelle midler på kort tid sat en meget effektiv stopper for korruption inden for vand- og elforsyningen. Aktivismen har dog på det seneste sat solide spørgsmålstegn ved partiets midler, men ikke målet. Det kan true partiets ambition om at spille en rolle ved det forestående parlamentsvalg.

Valget bliver derfor med stor sandsynlighed en tvekamp mellem BJP og Kongrespartiet, personificeret af Modi og Rahul. Tvekampen vil sætte en uprøvet politiker op mod en dreven politiker, der tillige har fordelen af at have været chiefminister. Det synes at blive en ulige kamp.

\section{Ændret politisk landskab}

Indiens politiske landskab har over tid skiftet karakter og har skabt grundlaget for en række såkaldt regionale partier. Partier, som har udspring i den konkrete delstat, og som tillige har deres vælgerbase $\mathrm{i}$ bestemte befolkningsgrupper. Det gælder især Vestbengalen, Uttar Pradesh, Odissa samt Tamil Nadu. Disse meget forskellige partier forsøger sammen med det noget hensygnende Kommunistparti - at skabe en såkaldt tredje front. Disse partier vil sikkert få nogen succes, men når valgets vinder skal kåres, vil flere af disse partier formentlig søge indflydelse. Dette tilsiger støtte til en Modi-ledet regering.

Pilen peger i stigende grad henimod en valgsejr for Modi. Det store spørgsmål er, hvorvidt han vil være i stand til at opnå det krævede antal mandater. Absolut flertal kræver mindst 272 mandater. Det kan være inden for rækkevidde. Mest sandsynligt er det dog med en stor valgsejr, som lander lige omkring 200 mandater, hvorefter der vil være behov for støttepartier. Dette vurderes ikke umiddelbart at være et problem.

Den generelle vurdering er, at Kongrespartiet vil tabe endog meget stort. Dermed fortsættes trenden fra de i november og december sidste år afholdte delstatsvalg blandt andet i Delhi, Madhya Pradesh og Rajasthan, hvor Kongrespartiet tabte historisk stort. Flere og flere iagttagere vurderer, at dette meget vel kan være afslutningen på Gandhifamiliens æra. Hovedmodstanderen Modi lægger ikke skjul på, at han gerne ser dette. Såfremt det sker, vil en æra i indisk politik være tæt på en afslutning. Det anerkendes, at 
Gandhi-dynastiet og Kongrespartiet bragte frihed til nationen, men denne er ikke omsat til fortsat og konkret frihed til middelklassen. Den ser sig om efter nye ledere, som kan indfri dens personlige ønsker og ambitioner såsom økonomisk og social frihed samt uddannelse og job.

\section{Et nyt Indien}

De indiske vælgere vil afgøre personvalget. Uanset hvem der vinder, kan valgets betydning ikke undervurderes. Indien kan og skal forandre sig. Vælgerne søger efter en effektiv og handlekraftig leder. Meget tyder på, at det også vil ske.

Med valget vil et nyt Indien blive formet. Et Indien, hvor korruption effektivt vil blive bekæmpet, hvor politiske reformer vil blive iværksat og gennemført. En effektiv politisk ledelse vil målrettet gå efter at udløse de meget store potentialer, som Indien altid har haft og i voksende grad opbygger. Hovedfokus vil uforandret være at løse de hjemlige ud- fordringer. Det vil altid være hovedprioriteten for en indisk regering.

Indiens internationale ageren må dog også forventes ændret. En stærk regeringsleder, der effektivt kan sætte den indiske vækstmaskine tilbage på sporet, vil - alt andet lige, også engagere sig mere handlekraftigt på udenrigspolitikken og i internationale spørgsmål. Ikke at det nødvendigvis vil blive 'lettere', men et stærkt Indien vil, gennem effektiv håndtering af dets hjemlige udfordringer, være rede til at engagere sig håndfast i det internationale samarbejde. Dette vil uden tvivl også være i omverdenens interesse.

Det er dog vigtigt ikke blot at fremskrive Indien efter vestlige udviklingsmønstre. Vesten forandrer sig - og det gør Indien også.

Freddy Svane er Danmarks ambassadør $i$ Indien. Freddy Svane holdt i februar 2014 det sidste foredrag $i$ Det Udenrigspolitiske Selskabs møderceke 'BRICS and beyond'. Artiklen udtrykker Freddy Svanes personlige vurderinger. 